doi: $10.26529 /$ cepsj. 1003

\title{
Editorial
}

\section{The Development of Teacher Research as a Form of Developing Teacher Pedagogical Practice}

Although attention to research competence in teacher education curricula has increased, we are still faced with concerns over the lack of research culture in schools and the fact that teachers hardly ever use the results of scientific research to improve their practice (Van der Linden et al., 2015). In the last two decades, researchers have thoroughly studied the concept of research-based teacher education, which has included both training teachers as researchers and teacher educators engaging in integrating research evidence into their teaching. The topic of teacher as researcher - also known as practitioner research - has become an important concept in academic research and it is thus crucial to examine how the debate around this concept has evolved and how this research agenda will advance further.

The idea of teachers engaging in research practice is not entirely new. It was introduced much earlier and various related concepts have been studied in recent decades. In this regard, we have seen the developments in action research as one form of practitioner research. Carr and Kemmis (1986, p. 118) defined action research as a form of self-reflecting enquiry undertaken by participants in social situations in order to improve the rationality and justice of their own practices as well as their understanding of these practices and the situations in which the practices are carried out. Another great impetus for the development of the "teacher as a researcher" movement was the work of David Schön. His books The Reflective Practitioner: How Professionals Think in Action (1983) and Educating the Reflective Practitioner (1991) were a great contribution to the notion of teachers acting as reflective practitioners. The discourse of the reflective practitioner emphasises the particular skills needed to reflect constructively upon ongoing experience as a way of improving the quality and effectiveness of one's work.

Since then we have seen the evolution of the reflective practitioner concept into teacher or practitioner research. One important element of the debate around teacher research has been the notion of research literacy or teacher preparation to engage in research practice. Research literacy is understood as the ability to locate, understand, discuss and evaluate different types of research, to communicate accurately about them, and to use findings for academic and professional purposes (Beaudry \& Miller, 2016). This implies the need to advance the concept of routine reflection towards more systematic action on the 
part of teachers in collecting and interpreting data in order to make sense of their realities and to suggest improvements to practice in an evidence-based manner.

The increasing interest in developing teachers as researchers has in part occurred due to the advancements in defining teacher professionalism, on the one hand, and the permanent changes of classroom realities, on the other. The latter is closely connected to the ever increasing demands on the teaching profession to respond to the complexity of learning, as well as to the various societal phenomena present in todays' societies that in one way or another have a direct impact on what teachers do in school. In this context, teacher education has been responding to these developments in the changing role of teachers in the school setting. In response to the new teacher professionalism and the need for training teachers as researchers, teacher education practice has moved towards the academisation of teacher education by introducing more research skills training and theoretical academic preparation of new teachers.

The question that educators and policymakers therefore rightly ask is: What is a good model of developing teacher as researcher? The framework used for examining the development of teacher as researcher includes the dimensions internal to teachers, the length and quality of the training they are provided, and the school context in which teachers' work is embedded. The answer to the above question is therefore linked to the answers to following sub-questions:

What purpose should teacher research serve?

What are the minimal research skills that teachers need in order to engage in classroom research and how can teachers be best trained for this?

What are good methods of motivating teachers to engage in researching their own practice?

In what ways should school culture support teacher engagement in researching their practice?

This focus issue of the CEPS Journal attempts to contribute to the debate on the teacher as researcher movement in line with the questions raised above. It does so by providing a number of research articles related to the central theme of the issue.

The first article, Praxis, Pedagogy and Teachers' Professionalism in England, written by Andrea Raiker, provides an outline of the evolution of teacher professionalism in England and the way current teacher education practices support the advancement of teacher research practices. The article also provides a solid theoretical discussion of the importance and practicalities of developing teacher research. 
The second article, Educational Research Within the Curricula of Initial Teacher Education: The Case of Slovenia is written by Tina Štemberger. The article is an analysis of teacher education curricula in Slovenia in order to understand the realities of how the concept of research is reflected in the curricula. The research shows that initial teacher education programmes mostly include a course on developing research skills. However, the study highlights the concern that many master's programmes do not include research skills courses and calls for teacher education institutions to address the concept of teacher as researcher in a comprehensive way by recognising it as a form of teacher professional development.

The third article, Teacher-Researcher Development? Unpacking the Understandings and Approaches in Initial Teacher Education in Kosovo, is written by Fjolla Kaçaniku. It provides a rich and complex picture of how the teacher research concept is reflected in Kosovo teacher education by analysing teacher education curricula and gathering data from teacher educators and student teachers. The findings support the conclusions: i) the understanding of the teacher-researcher concept within initial teacher education is influenced by teacher educators' field of study as well as programme goals and values, ii) teacher educators and programme values and goals influence the development of teacher-researchers and can adversely impact on future teachers' practical engagement in research, and iii) the conflicting institutional governing variables prompt a fragmented context of teacher-researcher development that emphasises the need for coherence. Thus, the research recommends a more holistic approach to addressing the concept of teacher research within teacher education practices.

The fourth article, Motivational and Demotivational Factors Affecting a Teacher's Decision on Whether to Do Research, is written by Andrej Šorgo and Jasmina Heric. Their study involved 325 teachers in an online survey with the aim of understanding the readiness and activity of teachers regarding scientific research. The teachers surveyed predominantly reported that they were prepared to engage in research, although only a quarter of them reported actually having been engaged in research. An intrinsic motivation for research and career goal orientation were reported as the main drivers for teachers to engage in research, while lack of time for research, family life and school culture were considered the main factors that hinder teacher engagement in classroom research.

The fifth article, Teachers as Embedded Practitioner-Researchers in Innovative Learning Environments, is written by Wesley Imms, Joanne Blannin, Marian Mahat, Benjamin Cleveland and Julia Morris. Their research was 
conducted in the context of Australia and New Zealand, and it emphasises the importance of structured time and processes for teachers in schools in order to engage in research, as well as the need for school leadership to recognise the value of investing this time. In addition, the research emphasises the need to promulgate and disseminate school-based research both inside and outside the school, so that the practice is widely recognised and supported.

The present focus issue is complemented with two articles from the Varia section and two book reviews. The first Varia article is written by Siti Zubaidah, Susriyati Mahanal, Mar'atus Sholihah, Fatia Rosyida and Zenia Lutfi Kurniawati, and is entitled Using Remap RT (Reading - Concept Mapping - Reciprocal Teaching) Learning Model to Improve Low Ability Students' Achievement in Biology. The main aim of this study was to investigate the effects of the Remap RT (Reading - Concept Mapping - Reciprocal Teaching) learning model on low-ability students' achievement in biology. The results of the research suggest that Remap RT was effective in improving low-ability students' achievement in biology and is suggested as an adequate teaching strategy.

The second Varia article is written by Edona Berisha Kida and Theodhori Karaj and is entitled Development of an Albanian Version of the Questionnaire on Teacher-Student Interaction. The purpose of the article was to adapt an English version of a teacher student questionnaire, creating an Albanian version. The original 64 items of the survey were reduced to 54 items in the Albanian version, which was tested in the Kosovo context to ensure its fitness for purpose.

Žan Korošec reviews a book published by Janez Vogrinc and Blerim Saqipi entitled Research in Education Sciences. Conceptual and Methodological Perspectives (Published by Albas in Tirana (Albania), 2019; 112 pp.: ISBN: 978-9928-282-69-9), and Damijan Štefanc reviews a book published by Mojca K. Šebart and Andreja Hočevar entitled Delusions of preschool education: Does anyone care about the process quality anymore? Verlag Dr. Kovač (2019; 133 pp.: ISBN: 978-3-339-11112-8).

In conclusion, the five articles related to the focus issue theme of developing teacher as researcher provide a solid basis for examining the concept of teacher research in the necessary breadth and depth. In view of the above, the aim of research-based teacher education - as a broader concept - should not necessarily be seen as being equal to training researchers. Developing teacher as researcher can be viewed as a combination of equipping teachers with research skills, on the one hand, and training them as much as possible in the realities of school, on the other (Mynthe \& Rogne, 2015; Niemi \& Nevgi, 2014). Hence, teacher research is now seen as a process of engaging teachers in professional 
learning and development through reflective and inquiry practice, combined with their classroom-based research activity.

Teacher as researcher and research competence in teacher education programming must now be addressed in the continuum of pre-service and inservice teacher education. Teacher research is much more than knowing about research, and teachers need to be educated and practically exposed to the process of actually doing research during their training. We cannot ignore the fact that it is now time to look at the dimensions of the trustworthiness of teacher research. However, more research and development work needs to take pace first to identify ways in which teachers can be best prepared for the research task and how this role can be best integrated within their duties in the school and the expectations of the teaching profession. Only then will teacher research be able to translate into meaningful professional learning and school development, which need to be experienced, acknowledged and supported by all stakeholders in school.

BLERIM SAQIPI AND JANEZ VOGRINC

\section{References}

Beaudry, J. S., \& Miller, L. (2016). Research literacy. A primer for understanding and using research. The Guilford Press.

Carr, W., \& Kemmis, S. (1986). Becoming critical: Knowing through action research. Deakin University. Niemi, H., \& Nevgi, A. (2014). Research studies and active learning promoting professional competences in Finnish teacher education. Teaching and Teacher Education, 43, 131-142.

Mynthe, E., \& Rogne, M. (2015). Research based teacher education. Teaching and Teacher Education, 46, $17-24$.

Schön, D. A. (1983). The reflective practitioner. Basic books.

Schön, D. A. (1991). Educating the reflective practitioner. Jossey-Bass Publishers.

Van Der Linden, W., Bakx, A., Ros, A., Beijaard, D., \&Van Der Bergh, L. (2015). The development of student teachers research knowledge, beliefs and attitudes. The Journal of Education for Teaching, 41(1), 1-16. 